\title{
About some peculiarities of calcephyte flora of the Small-Amalatian depress (Northern Transbaikalia)
}

\author{
Evgenia Pyzhikova $^{1 *}$, Marina Tsyrenova ${ }^{1}$, and Igor Novolodskij ${ }^{1}$ \\ ${ }^{1}$ Buryat State University named after D. Banzarov, Russia
}

\begin{abstract}
The article is devoted to the study of the calcephyte flora of the Small-Amalatian depress. The main objective of the study is to carry out floristic analysis of limestone outcrops. The calcephytic flora was analyzed on the longitudinal element, biomorphological, taxonomic and ecological analyzes were carried out.
\end{abstract}

\section{Introduction}

The calciferous outcrops in Malo-Amalatskaya Depression in the area of the cryophyte black hemlock forests are distinguished by original flora and vegetation that is due to the substrate peculiarities, geographical location and history of the studied territory [1]. The fragmentary calciferous outbursts in the territory of the East Siberia that have been formed for millions of years are particularly valuable to get to know the peculiarities of florogenesis of the North Asia, these are the localities where the relic elements of the Pleistocene cold ages have put down roots and preserved until now [2, 3, 4]. The calciferous flora of Malo-Amalatskaya Depression was studied by the staff members of the Botanics Department Buryat State University named after D. Banzarov.

The natural conditions of the studied area are characterized by ultracontinentality with the prevailing below-freezing average annual temperatures (from $-2^{\circ}$ to $-6^{\circ}$ ), short freezefree period (35-60 days), small amounts of precipitations primarily (up to $300 \mathrm{~mm}$ ), falling in the second half of the summer and ubiquitous perpetually frozen ground. All these predetermine a high degree of peat formation in the studied territory in the background of the general relief evenness with interleaving low-rise steep slope ridges. By physical and geographical zoning, this territory belongs to the Transbaical mid-mountain-upland and Transbaical basins of the region, Vitimskaya upland province [5].

Malo-Amalatskaya Depression (pic. 1) - is one of the Meso-Cenozoic basins of the central part of the Vitimsky upland [6], with the bottom elevated to 1,000 $\mathrm{m}$ above-sea level. The north-west margins of the depression are formed by the calciferous rocks laying on schists and granites, with basalts occasionally occurring.

\footnotetext{
* Corresponding author: gp777@yandex.ru
} 


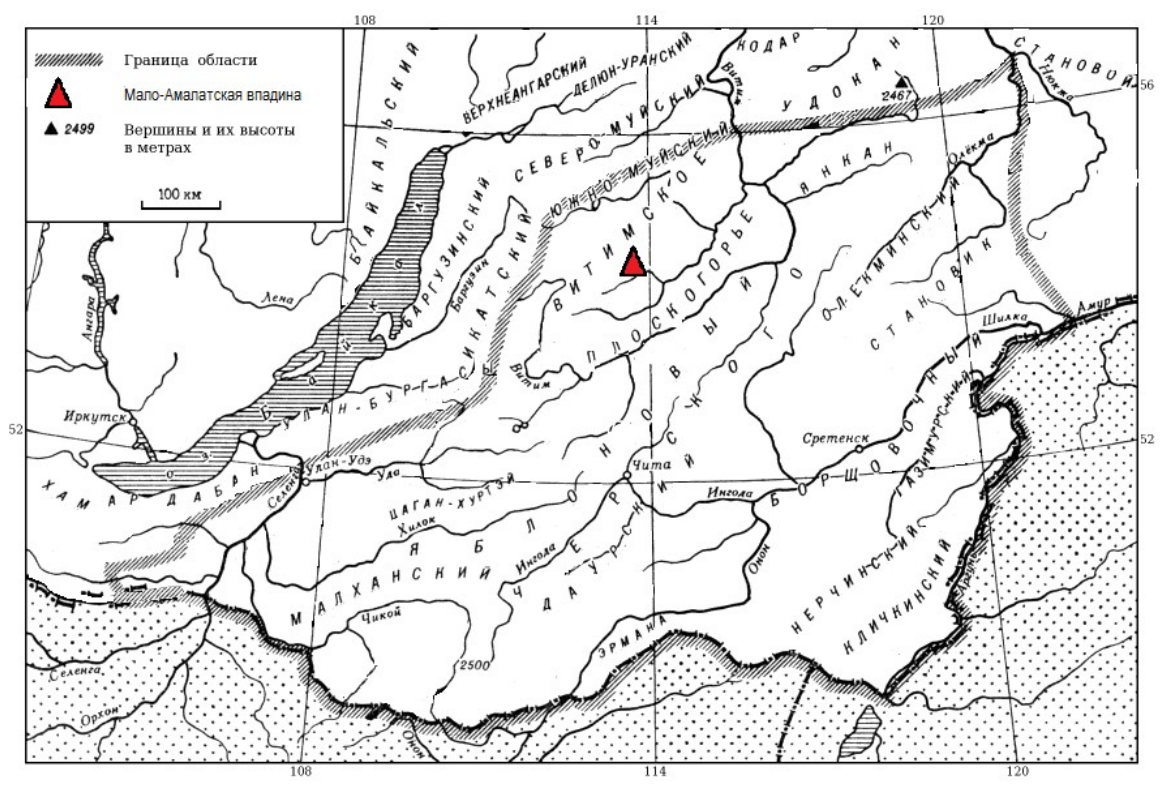

Fig. 1. Map of the location of the study area

The outcrops are characterized by erosion processes, they are particularly developed in the surrounding area of Bagdarin where the south slopes form narrow valleys, ridges and outliers. The tops of the monolithic rocks are covered by loose rubble layer (to $5 \mathrm{~m}$ thick), with the occasionally occurring slide rocks flowing like tongues to the bottom of the mountain (Fig. 2).

\section{Materials and Methods}

We have conducted the floristic studies in three key areas: 1. Belaya (Bagdarin), Bagdarinka river bottom (left-bank tributary of Malyi Amalat), absolute height $1499 \mathrm{~m}$ above sea level, 54.454694 north latitude 113.595158 east longitude; 2. Mount Izvestka, valley of the Anik river (right tributary of the Bagdarynka river), altitude $1203 \mathrm{~m}$ above sea level, 54.452832 north latitude 113.442349 east longitude. ; 3. Belaya mountain (Baghdahali tract), Berezovyj brook, valley of the Tocher river (left tributary of the Malyj Amalat river), height 1346, 54.439261 north latitude 113.227184 east longitude.

\section{Results and discussion}

The plant cover of all the studied territories is non-uniform. It is characterized by unevenness, low general projective cover (GPC) and low-rise species diversity.

Of woody plants, Larix dahurica Lawson is ubiquitous (hereinafter the names are given according to: "Abstract of the flora of Asian Russia") [7], on the town of Belaya (Bagdarin), a small-stemmed pine from Pinus sylvestris L. grows on a small contour in the upper part Belaya (Bagdakhali) is a crooked forest from Larix dahurica, one individual of the creeping Pinus sibirica Du Tour and three oppressed individuals of Picea obovata Ledeb were found. Aspen (Populus tremula L.) and birch (Betula pendulla Roth.) forests are noted in the middle and upper parts of the forested mountain of Izvestka. 

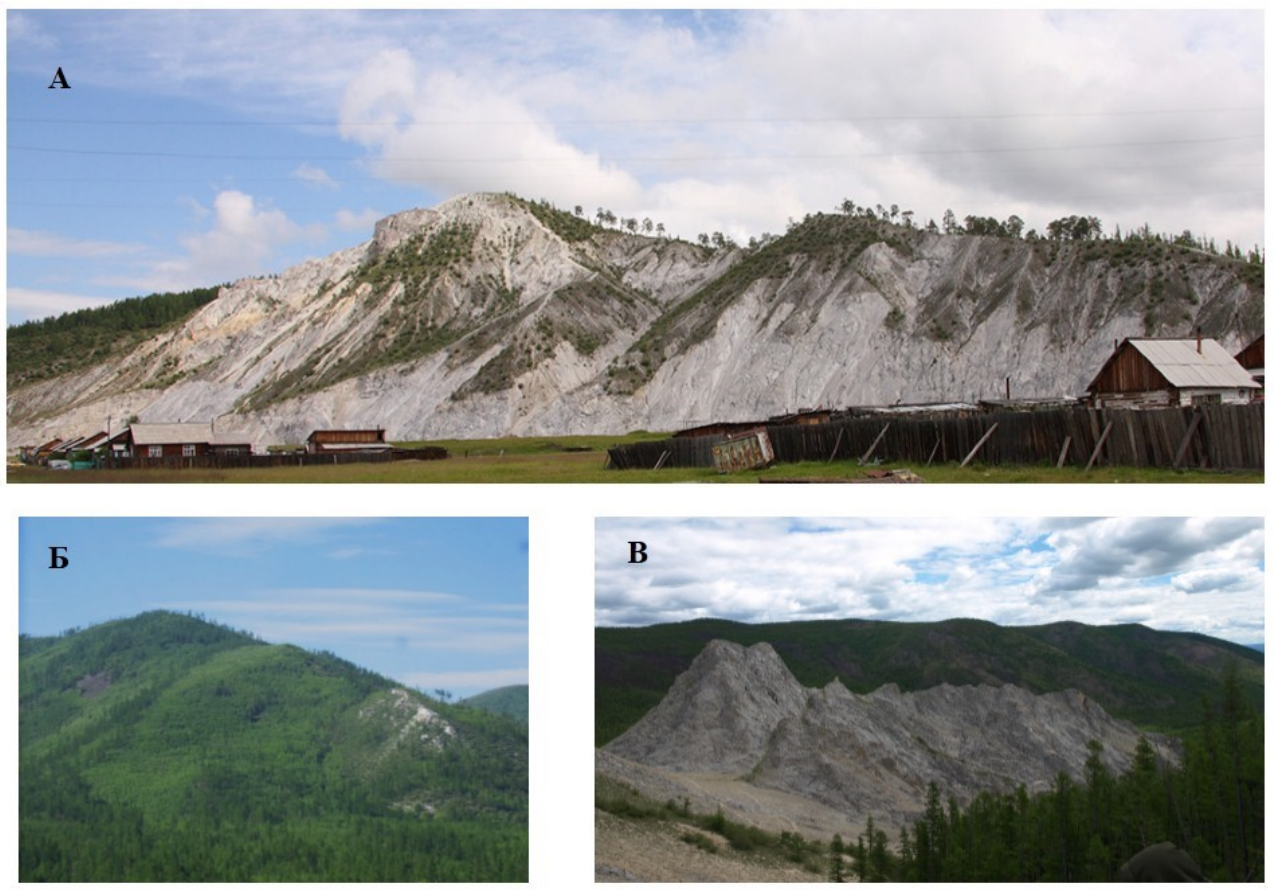

Fig. 2. General view of the limestone outcrops of the Malo-Amalatskoj depression: A - Mount Belaya (Bagdarin settlement), B - Mount Izvestka (river Aunik), C - Mount Belaya (Baghdahali tract).

The calciferous flora of the studied territory is represented by 47 families, 105 genuses and 163 species. The angiosperms $(92.02 \%)$ are dominating, and the cryptograms and gymnosperms are minimum (4.2 and 3.6\%, respectively). 12 families are leading and make $66.26 \%$ of the flora. The flora formation, uniqueness and development reflect the smallspecies families that made almost a half of the entire flora $-46.80 \%$. The quantitative characteristics of the flora are given in Table 2.

Table 1. Quantitative characteristics of the flora of the Amalat river basin

\begin{tabular}{|c|c|c|c|}
\hline \multicolumn{2}{|l|}{ Index } & Absolute number & $\begin{array}{l}\text { Percent } \\
\text { participation }\end{array}$ \\
\hline \multicolumn{2}{|l|}{ Species } & & 100 \\
\hline \multicolumn{2}{|l|}{ Genus } & & 100 \\
\hline \multicolumn{2}{|l|}{ Families } & & 100 \\
\hline \multicolumn{2}{|c|}{ Species in 12 leading families } & & 63,19 \\
\hline \multicolumn{2}{|c|}{ 1-species families } & & 46,80 \\
\hline \multicolumn{2}{|c|}{1 species genus } & & 67,61 \\
\hline \multirow[t]{3}{*}{ Average } & $\mathrm{Sp} / \mathrm{G}$ & 1,55 & \\
\hline & $\mathrm{G} / \mathrm{F}$ & 2,23 & \\
\hline & $\mathrm{Sp} / \mathrm{G}$ & 3,47 & \\
\hline
\end{tabular}

The spectrum of the leading families is headed by Asteraceae, Ranunculacea and Rosaceae that is characteristic for the flora of Baikal Siberia (Table 3). The environmental analysis of the leading families' representatives showed the average out share of species of mesophytic and xerophytic ecology. This is explained by that the species acclimatized to the lacking humidity and severe solar radiation predominate at the steep calciferous slopes, and the increased humidity and bogginess that is aggravated by near occurrence of the perpetually frozen grounds are observed in the bottom. By comparing the spectrum, in general, with the 
flora of Amalat river basin [8], the high rank-performance of the Ericaceae, Orchidaceae and Pinaceae families can be observed. Such high concentration of the representatives of these families is characteristic for calcareous rock of the studied territory. The genus spectrum is headed by Salix (Table 2), these are mainly the forest species of willows but the species of the highland and mountainous general zone complex that are the obligate calciphytes are of particular interest: Salix saxatilis Turcz. ex Ledeb., S. fuscescens Andersson, S. nummularia Andersson. The top position is occupied by the Festuca genus where such endemic species as Festuca hubsugulica Krivot. and F. komarovii Krivot should be pointed out, at this, the interspecies were found out.

Table 2. The spectrum of leading families and genera of flora

\begin{tabular}{|c|c|c|c|c|c|c|}
\hline № & families & $\begin{array}{l}\text { The absolute } \\
\text { number of } \\
\text { species }\end{array}$ & $\begin{array}{l}\text { Number of } \\
\text { genus }\end{array}$ & № & Genus & $\begin{array}{l}\text { The } \\
\text { absolute } \\
\text { number } \\
\text { of } \\
\text { species }\end{array}$ \\
\hline 1 & Asteraceae & 15 & 9 & 1 & Salix & 7 \\
\hline 2 & Ranunculaceae & 14 & 10 & 2 & Carex & 6 \\
\hline 3 & Rosaceae & 13 & 8 & 3 & Pedicularis & 5 \\
\hline 4 & Poaceae & 10 & 5 & $4-5$ & Festuca & 4 \\
\hline 5 & Fabaceae & 9 & 6 & $4-5$ & Saussurea & 4 \\
\hline 6 & Salicaceae & 8 & 2 & $6-12$ & Pinus & 3 \\
\hline 7 & Cyperaceae & 7 & 2 & $6-12$ & Equisetum & 3 \\
\hline $8-9$ & Ericaceae & 6 & 4 & $6-12$ & Silene & 3 \\
\hline $8-9$ & Orchidaceae & 6 & 4 & $6-12$ & Thalictrum & 3 \\
\hline $10-12$ & Pinaceae & 5 & 3 & $6-12$ & Potentilla & 3 \\
\hline $10-12$ & Caryophyllaceae & 5 & 3 & $6-12$ & Astragalus & 3 \\
\hline $10-12$ & Scrophulariaceae & 5 & 1 & $6-12$ & Artemisia & 3 \\
\hline Total: & & 103 & & & & 47 \\
\hline
\end{tabular}

This is shown by Table 4. If to exclude the group of forest species from the analysis (as the occurrence of the regional element of the vegetation in the studied territory), the species of the highland and mountainous general zone and steppe floristic complex are equally observed (approximate 27\% each). The calciferous outcrops can be considered "as the bed in the historical process of phylocoenogenesis" for calciferous formations of the cryoarid periods of the Pleistocene. We have observed the listed species only on the carbonate substrates in the studied territory, with the most species wealth in Bagdakhali stow [9].

Obligatory calcephites are Oxytropis triphylla (Pall.) Pers., Dryas sumneviczii Serg., Gypsophila sambukii Schischk., Paraquilegia microphylla (Royle) J. Drumm. et Hutch. , Lloydia serotina (L.) Rchb., Callianthemum sajanense (Regel) Witasek, Saxifraga oppositifolia L., Caragana jubata (Pall.) Poiret., Primula xanthobasis Fed., Spiraea alpina Pallas., Saussurea schangliana (Wydl.) Fisch. and other. The listed species in the study area were noted by us only on carbonate substrates, with the highest species richness in the Baghdakhali tract.

Table 4. The ratio of species in the belt-zonal groups (BZG) and Horological groups of flora

\begin{tabular}{|c|c|c|c|c|c|c|c|c|c|c|c|c|c|c|}
\hline \multirow{2}{*}{ BZG } & \multicolumn{10}{|c|}{ Horological groups } & \\
\cline { 2 - 15 } & C & AA & Eu & ES & PA & NA & SS & CA & NA & EA & MD & O & En & Total: \\
\hline HA & & & & & & 1 & 1 & 1 & & & & & 1 & 4 \\
\hline TH & 7 & 3 & & & & 2 & & & 1 & & & & & 13 \\
\hline MV & 1 & & & & 2 & 7 & 4 & 1 & 2 & & & & 2 & 19 \\
\hline
\end{tabular}




\begin{tabular}{|c|c|c|c|c|c|c|c|c|c|c|c|c|c|c|}
\hline HM & 7 & 1 & 1 & & & & & & & & & & & 9 \\
\hline Total: & 15 & 4 & 1 & & 2 & 10 & 5 & 2 & 3 & & & & 3 & 45 \\
\hline $\mathrm{DF}$ & 4 & 1 & 2 & 2 & & & 1 & & & 1 & & & & 11 \\
\hline $\mathrm{LC}$ & 12 & 2 & 9 & & 2 & 10 & 8 & & 2 & 5 & 2 & 1 & & 53 \\
\hline $\mathrm{Pb}$ & & & 1 & 1 & & 1 & & & & 1 & 1 & 1 & & 6 \\
\hline Total: & 16 & 3 & 12 & 3 & 2 & 11 & 9 & & 2 & 6 & 3 & 2 & & 70 \\
\hline $\mathrm{FS}$ & & & 5 & 1 & 1 & 1 & 1 & 1 & 1 & 1 & 1 & & & 13 \\
\hline $\mathrm{MS}$ & & & 4 & & & 2 & 7 & 2 & & 2 & 5 & & 2 & 24 \\
\hline $\mathrm{S}$ & & & 1 & & & 1 & 2 & 1 & & & & & & 5 \\
\hline Total: & & & 10 & 1 & 1 & 4 & 10 & 4 & 1 & 3 & 6 & & 2 & 42 \\
\hline $\mathrm{M}$ & 1 & & 2 & 1 & & & & & & 1 & & & 1 & 6 \\
\hline Total: & 1 & & 2 & 1 & & & & & & 1 & & & 1 & 6 \\
\hline Total: & 32 & 7 & 25 & 5 & 5 & 25 & 24 & 6 & 6 & 10 & 9 & 2 & 6 & 163 \\
\hline
\end{tabular}

Note: HA - high-altitude, TH - tundra-high-altitude, MV - mountain, $\mathrm{H}$ - hyarctic, DF - dark coniferous forest, LC - light coniferous, $\mathrm{Pb}$ - preboreal, FS - forest-steppe, MS - mountain steppe, $\mathrm{S}$ - steppe, M- meadow ; C - circumpolar, AA - American-Asian, Eu - Eurasian, PA - pan-Asian, NA -north asian, SS - South Siberian, CA - Central Asian, NA - northeast asian, EA - east asian, En endemic, ES - Euro-Siberian, MD - Manchu-Daurian, O - Okhotsk.

The biomorphological analysis showed the prevalence of short creeping stem (37\%), taproot (18\%) and long creeping stem (15\%) grass as the result of adoption to the solid monolithic and moving rubble carbonate substrate. The creeping stem and firmbunch $(9 \%)$ grasses are more important on the loose rubble slopes. Of particular interest are plants with multi-headed caudex (clump plants [9]) - Oxytropis triphylla, Gypsophila sambukii, Phlojodicarpus sibiricus (Stephan ex Spreng.) Koso-Pol., Silene jenisseensis, etc.

\section{Conclusions}

Therefore, the flora analysis showed that the outcrops perform the function of refuges of the Pleistocene relics in drier and colder localities. The equal share of the Arctic-Alpine and steppe plants makes it possible to attribute these formations to the "steppe" ones that require further study and more profound florogenetic analysis.

This work was supported by a Global Greengrants Fund grant (2019, supervisor M.G. Tsyrenova) and an initiative grant from the Buryat State University named after D. Banzarov, No. 20-07-0502 (supervisor Pyzhikova E.M). The authors are thankful to O. N. Morozov (the Head of the speleological circle "Dolgan", Bagdarin, Bauntovsky district of the Republic of Buryatia) for much appreciated help in the joint expedition 2019.

\section{References}

1. Pyzhikova E.M., Tsyrenova M.G., Kholboeva S.A. Bulletin of the Buryat State University. 3, 39 (2016)

2. Alpine flora of the Highlands: composition, features, genesis. (Publishing House Science, Novosibirsk 1972)

3. Malyshev L.I., Peshkova G.A. Features and genesis of the Siberian flora (Prebaikalia and Transbaikalia). (Publishing House Science, Novosibirsk, 1984)

4. Gularyants G.M. Bulletin of the Botanical Garden Institute of the Far Eastern Branch of the Russian Academy of Sciences, 7, 94 (2010) 
5. Dambiev E.Ts., Bulletin of the Buryat State University, 3, 26 (1997)

6. Osokin P.V., Balkhanov V.V., Siberian Tectonics (Publishing House Science, Novosibirsk.. 1968)

7. Abstract of flora of Asian Russia: Vascular plants (Publishing House of the SB RAS, Novosibirsk, 2012)

8. Pyzhikova E. M. Flora of the Amalat River Basin: composition, structure and characteristics of economic use (Northern Transbaikalia). (Abstract. diss. cand. biol. science, Ulan-Ude. 2004)

9. Namzalov B.B.-Ts., Zhigzhitzhapova S.V., Taysaev T.T., Radnaeva L.D., Banaeva S.Ch., Namzalov M.B., Arid ecosystems, 24, 37 (2018). 